\title{
South Africa's latest medically assisted reproduction draft regulations: close, but no cigar*
}

\author{
DONRICH THALDAR** \\ BONGINKOSI SHOZI***
}

\author{
SAMEVATTING
}

\author{
DIE MEES ONLANGSE REGULASIES AANGAANDE MEDIES-GEASSISTEERDE \\ VOORTPLANTING: AMPER, MAAR NOG NIE STAMPER
}

\begin{abstract}
Medies-geassisteerde voortplanting in Suid-Afrika word tans gereguleer deur regulasies wat in 2012 gepromulgeer is ingevolge die Nasionale Gesondheidswet 61 van 2003. In Maart 2021 het die minister van Gesondheid nuwe konsepregulasies gepubliseer vir kommentaar. Hierdie artikel ontleed die nuwe konsepregulasies teen die agtergrond van groeiende regspraak in die gebied van medies-geassisteerde voortplanting, asook teen die agtergrond van nuwe tegnologiese ontwikkeling in hierdie gebied oor die afgelope dekade. In die eerste deel van die artikel word aspekte waarin die konsepregulasies verbeter het op die huidige regulasies uitgewys en ontleed, te wete (i) die nuwe, meer akkurate definisie van "gameetskenker"; (ii) die verhoogde perk op die hoeveelheid kinders wat verwek mag word met die gamete van 'n enkele skenker; (iii) die betrokkenheid van die direkteur-generaal in die vasstelling van vergoeding vir verskaffing van gamete; en (iv) die terugkeer na gemeenregtelike regulering van eienaarskap van gamete en in vitro embrio's. Die tweede deel van die artikel word toegespits op aspekte waarin die konsepregulasies verbeter behoort te word, naamlik (i) inkonsekwentheid en onsamehangendheid van verskeie definisies; (ii) die beperking dat spermselle slegs deur self-stimulasie bekom mag word vir medies-geassisteerde voortplanting; en (iii) die gebrek aan regulering van menslike oorerflike genoom-redigering. Die derde deel van die artikel verskaf 'n oorsig van die drie bepalings van die 2012 regulasies wat tans die onderwerp is van 'n grondwetlike hofsaak en wys hoe die 2021 konsepregulasies poog om die knelpunte in die hofsaak aan te spreek. Hierdie drie bepalings is (i) die vereiste dat 'n paartjie (hetsy getroud of in 'n permanente verhouding) hulself moet onderwerp aan sielkundige evaluasie indien hulle mekaar se gamete wil gebruik vir medies-geassisteerde voortplanting; (ii) die verbod op voor-inplantingstoetsing van in vitro embrio's vir nie-terapeutiese geslagseleksie; en (iii) die verbod op bekendmaking - deur énigiemand - van inligting oor mense wat gebruik gemaak het van medies-geassisteerde voortplanting, óf wat verwek is deur medies-geassisteerde voortplanting, óf wat gamete geskenk het vir medies-geassisteerde voortplanting. Die gevolgtrekking word gemaak dat die konsepregulasies 'n prysenswaardige poging is om op die bestaande regulasies te verbeter, maar dat dit nog in talle opsigte wesenlik tekort skiet. Ten einde hierdie tekortkominge aan te spreek, word omvattende aanbevelings gemaak oor hoe om die konsepregulasies aan te pas.
\end{abstract}

\section{Introduction}

Medically assisted reproduction is the international consensus term for reproduction that occurs through various interventions, procedures, surgeries and technologies to treat different forms of fertility impairment and infertility. ${ }^{1}$ Medically assisted reproduction includes, inter alia, ovarian stimulation, intravaginal insemination

* The authors would like to acknowledge the support of the National Research Foundation (Grant 116275) and the African Health Research Flagship, University of KwaZulu-Natal.

** Associate Professor, School of Law, University of KwaZulu-Natal.

**** Postdoctoral Research Scholar, Institute for Practical Ethics, UC San Diego.

1 Zegers-Hochschild et al "The international glossary on infertility and fertility care, 2017" 2017 Fertility and Sterility 393. 
with semen, and all procedures using assisted reproductive technology. ${ }^{2}$ Assisted reproductive technology, in turn, is the international consensus term for all interventions that entail the in vitro handling of human oocytes and sperm or embryos for the purpose of reproduction. ${ }^{3}$ Assisted reproductive technology includes, inter alia, in vitro fertilisation, embryo transfer, intracytoplasmic sperm injection, embryo biopsy, pre-implantation genetic testing, gamete and embryo cryopreservation, and semen, oocyte and embryo donation. ${ }^{4}$ Worldwide, between 1978 and 2011 more than seven million people were conceived through assisted reproductive technology. ${ }^{5}$ In her judgment in $A B v$ Minister of Social Development, ${ }^{6}$ Khampepe $\mathrm{J}$ reflected on assisted reproductive technology as follows:

"We are fortunate, however, to live in an era where the effects of infertility can be ameliorated to a
large extent through assistive reproductive technologies. The technological advances seen over the
last half century have greatly expanded the reproductive avenues available to the infertile. These
reproductive avenues should be celebrated as they allow our society to flourish in ways previously
impossible."

In South Africa, assisted reproductive technology - and medically assisted reproduction more broadly - are governed by (i) chapter 8 of the National Health Act 61 of 2003; (ii) certain sections of the Children's Act 38 of 2005 ; $^{8}$ and (iii) the Regulations Relating to the Artificial Fertilisation of Persons, ${ }^{9}$ promulgated in 2012 (the 2012 regulations). In 2016, new draft regulations ${ }^{10}$ were published for public comment (the 2016 draft regulations). However, these latter draft regulations never made it into law. ${ }^{11}$ In March 2021, revised draft regulations ${ }^{12}$ were published for public comment (the 2021 draft regulations). These new 2021 draft regulations are the focus of this article.

Over the past nine years since the promulgation of the 2012 regulations, a number of new technologies have affected the field of medically assisted reproduction and gynaecology more generally. These new technologies include, most pertinently, non-invasive prenatal testing (NIPT) which allows a pregnant woman to test her embryo for chromosomal abnormality at ten weeks of pregnancy, and CRISPRCas9, which places heritable human genome editing within reach. In this article, we analyse whether the 2021 draft regulations keep up with these technological developments.

In addition to technological advancement, there has also been significant legal development in recent years. The past decade has seen burgeoning case law in the field of medically assisted reproduction. The $A B$ case, mentioned above, dealt with the statutory requirement that surrogacy commissioning parents must use their own

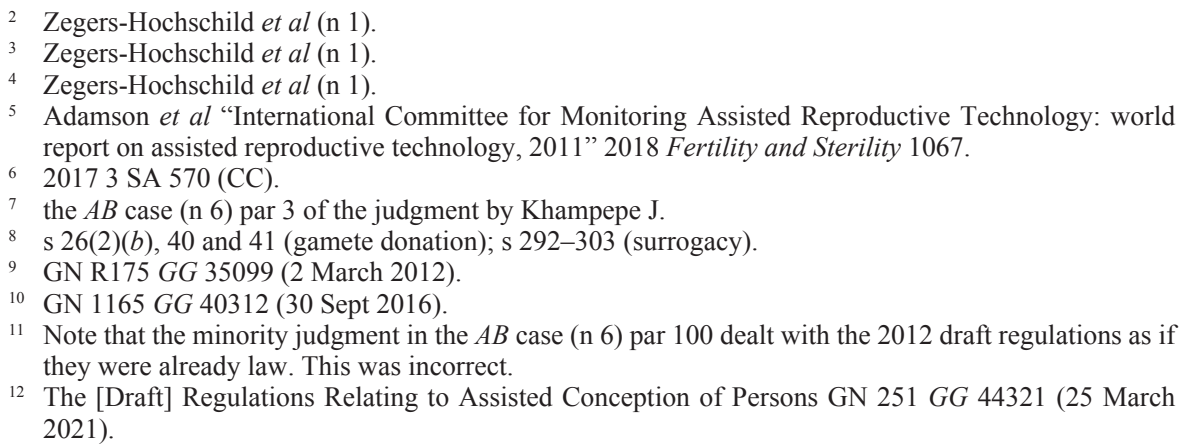

11 Note that the minority judgment in the $A B$ case (n 6) par 100 dealt with the 2012 draft regulations as if they were already law. This was incorrect.

12 The [Draft] Regulations Relating to Assisted Conception of Persons GN 251 GG 44321 (25 March 2021). 
gametes for the conception of the prospective child; ${ }^{13}$ Nurture Egg Donors CC v Minister of Health was settled before its hearing in court but highlighted the issue of payment in respect of the supply of gametes; ${ }^{14}$ Ex parte $K F$ clarified the concept of the prospective child by conceptually differentiating it from the in vitro embryo; ${ }^{15} \mathrm{NC} v$ Drs Aevitas Inc t/q Aevitas Fertility Clinic established that posthumous conception is legal; ${ }^{16}$ Ex parte $S N$ confirmed comatose gamete retrieval for posthumous conception was legal; ${ }^{17}$ and $Q G v C S$ dealt with the enforceability of sperm donor agreements. ${ }^{18}$

There has also been litigation that directly impugned aspects of the regulation (or proposed regulation) of medically assisted reproduction. First, in Pietermaritzburg Fertility Clinic (Pty) Ltd v Minister of Health, the new definition of "competent person" (which determines who can practise medically assisted reproduction) in the 2016 draft regulations was challenged as being unconstitutional. ${ }^{19}$ Although the case was ultimately dismissed because it was premature, it is nevertheless consequential, as the minister gave important undertakings regarding who can practise medically assisted reproduction. Secondly, Surrogacy Advisory Group v Minister of Health, filed in 2020, is a constitutional challenge to three provisions of the 2012 regulations. ${ }^{20}$ At the time of writing, legal proceedings in the Surrogacy Advisory Group case have been delayed by agreement between the parties to allow time for the respondent, the minister of health, to receive and consider feedback on the 2021 draft regulations, and, possibly, to promulgate new regulations that may resolve one, more, or all of the constitutional challenges by the applicant. Given that this case is sub judice and the first author of this article serves as counsel for the applicant, we provide only an overview of the three impugned provisions for the sake of comprehensiveness, but refrain from expressing any opinion on them.

This article is divided into three main parts. In the first part, we commence on a positive note by highlighting four aspects of the 2021 draft regulations that we suggest are improvements on their predecessors. In the second part, we turn our attention to three aspects of the 2021 draft regulations that we suggest require

13 (n 11). For discussions of the $A B$ case, see Boniface "The genetic link requirement for surrogacy: a family cannot be defined by genetic lineage" 2017 TSAR 190; Thaldar "Post-truth jurisprudence: the case of AB v Minister of Social Development" 2018 SAJHR 249; Meyerson "Surrogacy, geneticism and equality: the case of $A B v$ Minister of Social Development" 2019 Constitutional Court Review 321; Thaldar "The Constitution as an instrument of prejudice: a critique of AB v Minister of Social Development" 2019 Constitutional Court Review 343; Albertyn "Abortion, reproductive rights and the possibilities of reproductive justice in South African courts" 2019 University of Oxford Human Rights Hub Journal 108; Shozi "Something old, something new: applying reproductive rights to new reproductive technologies in South Africa" 2020 SAJHR 1.

14 (82891/15) 2016 ZAGPPHC 185 (8 April 2016). For an analysis of this case, see Bharath A Legal Analysis of Trade in Personal Information Regarding Human Gamete Donors (2018 LLM dissertation KZN).

1520192 SA 510 (GJ). For a discussion of Ex parte $K F$, see Thaldar "Criteria for assessing the suitability of intended surrogate mothers in South Africa: reflections on Ex Parte KAF II" 2019 S Afr J Bioethics Law 61; Thaldar "The in vitro embryo and the law: the ownership issue and a response to Robinson" 2020 PELJ 1; Thaldar and Shozi "Procreative non-maleficence: a South African human rights perspective on heritable human genome editing" 2020 The CRISPR Journal 32.

16 unreported case 23236/2017 ZAWCHC (23 Jan 2018). For a discussion of the $N c$ case, see Thaldar "Posthumous conception: recent legal developments in South Africa" 2018 S Afr Med J 471.

17 unreported case 10242/2020 ZAGPJHC (7 May 2020). For a discussion of the Ex parte $S N$ case, see Shozi "Legal issues in posthumous conception using gametes removed from a comatose male: the case of Ex parte SN" 2021 S Afr J Bioethics Law 5.

182021 ZAGPPHC 366.

192019 ZAGPPHC 479.

${ }^{20}$ case 50683/2020 ZAGPPHC. It is interesting to note that the Surrogacy Advisory Group was the second applicant in the $A B$ case (n 6). 
improvement before the 2021 draft regulations become law. In the third part, we provide a brief overview of the three impugned provisions of the 2012 regulations (and the corresponding provisions of the 2021 draft regulations, if any).

\section{Analysis of improvements made}

We identify and analyse four distinct improvements made in the $2021 \mathrm{draft}$ regulations: (i) the new definition of "gamete donor", (ii) restriction on gamete donation, (iii) compensation for gamete donation, and (iv) ownership of gametes and embryos.

\subsection{The new definition of "gamete donor"}

The concept of a gamete donor is ordinarily understood as reflecting someone who donates his or her gametes to other persons to be used in medically assisted reproduction. However, the 2012 regulations define a "gamete donor" more broadly than its normal meaning, which is "a living person from whose body a gamete or gametes are removed or withdrawn for the purpose of artificial fertilisation". This definition does not even include the concept of donation. It is so broad as to include a woman who undergoes egg harvesting for the purposes of her own fertility treatment, and her husband or life partner providing his own sperm with the view to the couple having children through medically assisted reproduction that are genetically their own. As is often the case when there is a discrepancy between the ordinary meaning of a term and its definition in legislation, the overbroad definition of "gamete donor" leads to strange results, since intended parents who use medically assisted reproduction healthcare services are treated as if they are gamete donors in the ordinary sense. One such example is that the "highest educational qualification" and "fields of interest" of intended parents must be recorded on their files held at their fertility clinic. This is clearly unnecessary. There are also other examples. ${ }^{21}$

The issue of the overbroad definition of "gamete donor" would be resolved by the new definition of "gamete donor" introduced by the 2021 draft regulations, namely "a living person from whose body a gamete or gametes are withdrawn or procured after stimulation for the purpose of donation for assisted conception" (emphasis added). By including the word "donation" in the definition, the 2021 draft regulations align the definition of "gamete donor" with its ordinary meaning. In other words, a couple who provide their gametes for their own use in medically assisted reproduction would no longer be dealt with as gamete donors. This is certainly an improvement, as it would avoid the strange outcomes of the 2012 regulations.

\subsection{Restriction on gamete donation}

The 2012 regulations restrict the number of times that a gamete donor's gametes may be used to six "children" that have been "conceived" using such donor's gametes. ${ }^{22}$ The 2012 regulations were criticised as being too restrictive in this regard. ${ }^{23}$ Furthermore, the use of the word "children" can be interpreted either

21 See par 4.1 (Psychological evaluation) below.

22 r 6(a), (b); r 8(2)(e).

23 Dhai "Limiting donor conceptions to six: time for change" 2014 S Afr J Bioethics Law 2. 
as children born, or as children born and still alive. ${ }^{24}$ The 2021 draft regulations address both these concerns by introducing: (i) a new maximum of twelve live births for a maximum of six recipients, and (ii) in the case of an egg donor, a maximum of six donations. ${ }^{25}$ Most importantly, from the perspective of legal certainty, the ambivalence of "children" is replaced with "live births".

\subsection{Compensation for gamete donation}

Whereas some jurisdictions allow free trade in gametes, others, such as South Africa, prohibit and criminalise the trade in gametes and allow gamete donors to be compensated only for reasonable costs incurred. ${ }^{26}$ However, the Southern African Society of Reproductive Medicine and Gynaecological Endoscopy (the society) published a guideline of R7 000 compensation for egg donors per donation. ${ }^{27}$ This is problematic in at least three ways. First, the society's membership is open only to healthcare practitioners working in the medically assisted reproduction industry, with no representation of donors or patients. ${ }^{28}$ As such, the society's guideline amounts to an interest group within the medically assisted reproduction industry (healthcare practitioners) agreeing not to pay a class of its suppliers (gamete donors) more than a certain amount. Whether or not this decision is lawful in terms of the Competition Act 89 of 1998 is an issue to consider, but suffice it to say the society lacks any form of legitimacy to exercise control over the remuneration of gamete donors. $^{29}$ Secondly, given that egg donors do not contribute to any of the medical costs involved in their donations, the only cost that an egg donor would typically incur on her own is her travel to the fertility clinic. If the egg donor has minor children, the cost of a babysitter for a day may also be factored in. However, in most cases, it is improbable that these expenses would ever come near R7 000. Thus it is difficult to see how this amount can be regarded as remuneration for costs incurred. Thirdly, although this guideline is no longer available on the the society website, it has become standard practice in the South African medically assisted reproduction industry to pay R7 000 per egg donation without any regard to actual expenses incurred. ${ }^{30}$ As such, the R7 000 generally serves as an incentive payment rather than as compensation for actual expenses incurred. This conclusion is amplified by the fact that South African egg donors on average earn R12 054 per month, hence

24 Dhai (n 23) interprets "children" that have been "conceived" as referring to embryos conceived. This interpretation cannot be correct. "Children" implies at the very least a live birth, and perhaps even more, namely a child that is still alive. However, "children" cannot refer to embryos in a petri dish, since in our law an embryo is not a child. In fact, an embryo is not even a prospective child. See the Ex parte $K F$ case (n 15) n 7.

$25 \mathrm{r} 7$.

26 s 60 of Act 61 of 2003 .

27 Thaldar "Egg donors' motivations, experiences, and opinions: a survey of egg donors in South Africa" 2020 PLOS ONE 1.

28 https://sasreg.co.za/about-sasreg/ (14-06-2021).

29 Note that members of the society sometimes promote the misguided notion that the society has the power to regulate the medically assisted reproduction industry in South Africa. For instance, Cape Fertility Clinic states as follows on its website (https://eggdonationcapefertility.co.za/egg-donationlegality/ (14-06-2021)): "The legal and ethical requirements for egg donation are set out by both the Department of Health and South African Society of Reproductive Medicine and Gynaecological Endoscopy (the society)." The notion that the society has the power to regulate the medically assisted reproduction industry in South Africa usurps the legitimate power of democratically elected officials in South Africa's government.

30 Thaldar (n 27); the Nurture case (n 14) replying affidavit par 59 ("the current reality in South Africa, namely that egg donors are, as a general rule, being paid R7 000 for donation"). 
making R7 000 an attractive sum of money. ${ }^{31}$ Accordingly, the current industry practice of paying R7 000 per egg donation without regard to actual expenses incurred clearly contravenes the law.

To address this state of affairs, Thaldar previously proposed to the department of health ${ }^{32}$ that the director-general must from time to time, after consultation with stakeholders (including patients and donors), publish guidelines regarding reimbursement of female and male donors. This proposal was incorporated in the 2021 draft regulations, ${ }^{33}$ and is a welcome development.

\subsection{Ownership of in vitro gametes and embryos}

Whereas the 2012 regulations contain provisions that allocate the ownership of in vitro gametes and embryos to specific persons, ${ }^{34}$ these provisions were removed from the 2021 draft regulations. We suggest that this is a change for the better, because the way in which ownership is allocated in the 2012 regulations is too rigid and biased in favour of one sex. By scrapping the ownership provisions, the 2021 draft regulations would usher a return to the common law position.

In order to justify our conclusion that this a positive development, it is necessary to outline the common law position on the ownership of in vitro gametes and embryos. Historically, human biological material (ie material that originates from, but is no longer part of a human body) was generally not viewed as susceptible of ownership. This view seems to find support in various passages in the Digesta, for example "liberum corpus aestimationem non recipiat" and "liberum corpus nullam recipit aestimationem", (which can both be translated as "the body of a free person is not susceptible of valuation"), and "dominus membrorum suorum nemo videtur",37 ("no one is deemed to be the owner of his own limbs"). These passages deal with the possibility of delictual claims for bodily injury. In this context, "limbs" are contemplated as part of the person's body. There is nothing that suggests that these passages are applicable to things, such as hairlocks that are used in wigs, ${ }^{38}$ that have been removed from a human body. Like such hairlocks, in vitro gametes are things that have been removed from the human body; and in vitro embryos are things that are created outside the human body by combining in vitro sperm and eggs. It would be an overbroad construction of these passages to make them applicable to in vitro gametes and embryos. Stated differently, in vitro gametes (directly) and embryos (indirectly) originated from a liberum corpus, but they are not the liberum corpus, nor part of it anymore - in vitro gametes and embryos each have a sui generis legal status of their own. For example, in vitro gametes and embryos can be imported

31 Thaldar (n 27).

32 email message from the first author to Motopi of the department of health, 28 May 2018.

r 5(2).

r 18.

D9 13.

6 D $9213 p r$.

$37 \quad D 937$.

38 In Roman times, as in our own, there seems to have been trade in human hair. Eg, in The Art of Love (Ars Amatoria 3.165), Ovid refers to "bought braids" ("crines empti"). On the topic of the use of human hair in ancient Rome in general, see Bartman "Hair and the artifice of Roman female adornment" 2001 American J Archaeology 1. 
and exported, ${ }^{39}$ used in research ${ }^{40}$ (and often destroyed in the process), ${ }^{41}$ used in medically assisted reproduction, ${ }^{42}$ or simply discarded when no longer wanted. In fact, cryopreserved embryos must be destroyed after ten years. ${ }^{43}$ None of these actions would be legally possible with a living liberum corpus. This highlights that one should guard against artificially stretching the passages in the Digesta to apply to a modern scenario that could not, despite all their wisdom, have been contemplated by our ancient forebears. In our current law, in vitro gametes and embryos have clearly each attained a sui generis legal status of their own.

Furthermore, the common law should develop in step with the dynamic and evolving fabric of our society. ${ }^{44}$ In this light, consider Grotius' definition of property as "Zaken noemen wy hier al wat daer is buiten den mensch, den mensch eenichsints nut zijnde",45 ("property is everything excluding or external to humans that has some use"). Human sperm, eggs and embryos outside the human body would undoubtedly have been useless in previous centuries. However, with the advent of medically assisted reproduction technologies, such as cryopreservation and in vitro fertilisation, in vitro sperm, eggs and embryos have become useful things. ${ }^{46}$ It follows, based on Grotius' definition, that these types of human biological material have become property - ie susceptible of ownership. ${ }^{47}$ Being susceptible of ownership does not mean that something is eo ipso within the sphere of commerce, ie tradeable. There are many instances of property that cannot be traded at all, or only subject to certain restrictions. Well-known examples are rhino horn, ivory, and marijuana. The same is true for in vitro gametes. Act 61 of 2003 provides that gametes may not be sold for profit; only reasonable costs incurred in the importation, exportation, acquisition or supply of gametes may be recovered. ${ }^{48}$ Interestingly, in vitro embryos are not included in this trade ban, as they are neither mentioned in the relevant section of the act, nor included in the act's definition of "tissue"."

The final reason that seals the conclusion that in vitro gametes and embryos are susceptible of ownership is that various pieces of legislation refer to the donation of gametes and embryos. ${ }^{50}$ Donation is a legal-technical term for a particular type of contract that entails a donor undertaking to give something to a donee without

39 The import and export of in vitro gametes and embryos are specifically regulated by the Regulations relating to the Import and Export of Human Tissue, Blood, Blood Products, Cultured Cells, Stem Cells, Embryos, Foetal Tissue, Zygotes and Gametes GN R181 GG 35099 (2 March 2012).

40 Research on in vitro gametes and embryos is specifically regulated by the regulations relating to the Use of Human Biological Material GN R177 GG 35099 (2 March 2012).

41 For example, when an embryonic stem cell line is developed from a human embryo, the embryo perish in the process. See Jordaan "Stem cell research, morality, and law: an analysis of Brüstle v Greenpeace from a South African perspective" 2017 SAJHR 429-451.

42 as regulated by the 2012 regulations ( $\mathrm{n} 9$ ).

$43 \mathrm{r} 10(2)(d)$ of the 2012 regulations (n 9).

44 DE $v$ RH 20155 SA 83 (CC) par 16.

45 Grotius Inleidinge tot de Hollandsche Rechts-Geleerdheid 213.

46 See Thaldar, Townsend, Botes and Shozi "Human biological material" in XXVI(1) LAWSA (2021) par 3.

47 Thaldar et al (n 46); Thaldar 2020 PELJ 1. For a comparative analysis of the law relating to human biological material, see Thaldar and Shozi "The legal status of human biological material used for research" (forthcoming in 2021 SALJ).

48 s 60(2)

49 s 1. For a detailed analysis of "tissue" as defined in Act 61 of 2003, see Thaldar and Shozi (n 47).

$50 \mathrm{~S}$ 60(4)(a) of Act 61 of 2003 refers to "donated" gametes; the 2012 regulations refer to the "donation" of gametes and to "donated" gametes in multiple provisions; the 2012 regulations also refer to "embryo donations" in $r 4$. 
the donor receiving any consideration in return or the expectation of a future advantage. $^{51}$ Importantly, performance in terms of a donation - delivering the donated thing - entails the transfer of ownership in the donated thing from the donor to the donee. ${ }^{32}$ Accordingly, by necessary implication, in vitro gametes and embryos must be susceptible of ownership. If this was not the case, the lawgiver would have used a non-legal-technical term that does not entail the transfer of ownership, such as "provided" gametes or embryos.

We now proceed to present our reasons why we suggest that the removal of the 2012 regulations' provisions that allocate the ownership of in vitro gametes and embryos to specific persons is a change for the better.

Firstly, in the case of sperm donors who do not donate for their wives, the 2012 regulations provide that their sperm is owned by the institution where they donated their sperm. ${ }^{53}$ This provision is ostensibly intended to facilitate anonymous sperm donors transferring ownership of their sperm to a sperm bank, which would then store and provide said sperm to fertility patients for the purpose of medically assisted reproduction. But in doing so, the 2012 regulations altered the common law position relating to sperm in a way that was ill considered, as it failed to consider men who wanted to store their sperm for their own future use and men who donate sperm to people whom they know - so-called known donors. There is no reason for a legal requirement that these men transfer ownership of their sperm to the institution where it is donated. Accordingly, the deletion of this provision in the $2021 \mathrm{draft}$ regulations is welcome.

Secondly, the ownership provisions of the 2012 regulations can be interpreted as placing unnecessary and unreasonable limitations on the freedom of persons to transfer ownership of their gametes and embryos. ${ }^{54}$ The removal of these provisions restores the common law freedom of persons to transfer their own property (in this case, in vitro sperm, eggs and embryos) to whomever they choose. Given the general ban of trade in gametes in Act 61 of $2003,{ }^{55}$ sperm and eggs cannot be sold, but ownership in them can be transferred by donation and inheritance.

In vitro embryos present an interesting problem: Since an embryo is the product of a sperm and an egg, who should own the embryo - the man or the woman? The 2012 regulations' solution is the woman, but why this should be the case is unclear. Since in vitro embryos are outside the woman's body, the rationale for this provision cannot be to protect the woman's bodily integrity. ${ }^{56}$ As such, there is no apparent reason to favour the woman, and consequently the 2012 regulations' solution is likely a violation of the constitution's equality clause. ${ }^{57}$ Regardless of its rationale, this provision is also excessively rigid. It leaves no space for an agreement between the man and the woman that they will be co-owners of the embryo, and there is no apparent reason why this should not be allowed. All it achieves is excluding men who contribute their gametes to the creation of an embryo from having an equal say in legal decisions pertaining to the said embryo. If the common law position is restored by the deletion of the 2012 regulations' ownership provision, as intended in

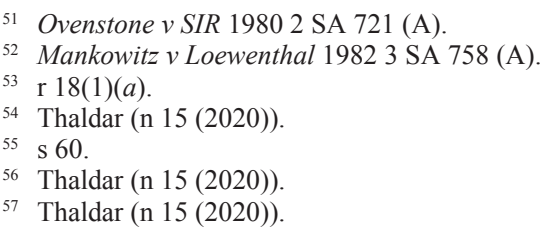


the 2021 draft regulations, parents would be free to agree on how they wish to deal with ownership and any specific rights in respect of the in vitro embryos.

\section{Analysis of aspects that require improvement}

We identify and analyse three aspects of the 2021 draft regulations that require improvement: (i) inconsistency and incoherence in the definitions, (ii) procurement of sperm only through self-stimulation, and (iii) preparing for the future of heritable human genome editing.

\subsection{Inconsistency and incoherence in definitions}

\subsubsection{General; the title}

The 2021 draft regulations introduce a number of new concepts and terminology. Unfortunately, the way this new nomenclature is defined and used is often confusing - an issue that is most prominently evident in the title. Whereas the 2012 regulations' full title is "Regulations relating to the artificial fertilisation of persons", the 2021 draft regulations' full title is "Regulations relating to the assisted conception of persons" (emphases added). The 2021 terminology of "assisted conception of persons" is a half-measure to update the outdated terminology and has problematic implications. The international consensus term is "medically assisted reproduction", not "assisted conception". In fact, the term "conception" was completely removed from the international consensus glossary and replaced by scientifically recognised terms such as "fertilisation". 58 Furthermore, the use of the words "conception of persons" in the title might be interpreted as implying that the product of conception is a person, which, in our law, is not true. Persons are born, not conceived. ${ }^{59}$

We suggest that the title should read "Regulations on medically assisted reproduction" (or "medically assisted reproduction regulations" in short). This will properly align the regulations with contemporary terminology. ${ }^{60}$ In the alternative, "Regulations on assisted reproductive technology" (or "assisted reproductive technology regulations" in short) can also be considered, although this would indicate a narrower scope. At issue is whether fertility treatments that do not need the highly specialised fertility healthcare services offered by fertility clinics, such as ovarian stimulation and intravaginal insemination - that fall within medically assisted reproduction but not assisted reproductive technology - and sperm donation for intravaginal insemination, ought to be regulated or not. Given that it is not difficult to do home inseminations with donor sperm, the policy question has privacy as well as practical enforcement dimensions: Ought the state to regulate what people do in the privacy of their homes, and is it practical to do so? These concerns are valid, but on the other hand the integrity of certain regulatory objectives, such as the limit on donations, would be compromised by limiting the regulatory scope to assisted reproductive technology.

It is remarkable that while the 2012 regulations include insemination and prescribe that it must be done at a fertility clinic, hence medicalising this procedure and simultaneously bringing it into the regulatory ambit, the 2021 draft regulations do not include insemination. The intention seems to be to move away from attempting

58 Zegers-Hochschild et al (n 1).

59 Christian Lawyers Association of South Africa v Minister of Health 19984 SA 1113 (T).

60 Zegers-Hochschild et al (n 1). 
to regulate all medically assisted reproduction and focus instead on assisted reproductive technology, which is the exclusive domain of fertility specialists and embryologists at fertility clinics. We suggest that the scope needs to be a policy decision by the minister of health after consultation with stakeholders.

Generally, greater care should be taken throughout the envisaged revised medically assisted reproduction / assisted reproductive technology regulations to use coherent, contemporary terminology.

\subsubsection{Avoid two terms for the same concept}

The definitions of "authorised institution" and "in vitro fertility clinic" are essentially identical, and thus having both is unnecessary and confusing. Either one should be removed, or there should be clarity regarding how they differ.

\subsubsection{Avoid unscientific, offensive language}

The definition of "genetic carrier" should omit reference to a disease-causing gene as a "faulty gene". This language is unscientific and may potentially offend individuals who have the disease caused by the said gene. The so-called "faulty gene" should be referred to as a "disease-causing gene".

\subsubsection{Rethinking the definition of "recipient"}

The definition of "recipient" has been changed to read "a female person into whose uterus or womb or fallopian tubes an embryo created using gamete [sic] from a donor is to be placed for the purpose of assisted conception". First, "uterus" is the Latin for "womb", hence using two terms is tautologous. Secondly, while the 2012 regulations' definition of "recipient" includes insemination with semen, this has been removed from the definition in the 2021 draft regulations. As remarked above, ${ }^{61}$ there seems to be an intention to move away from attempting to regulate all medically assisted reproduction and to focus instead on assisted reproductive technology. Thirdly, the phrase "from a donor" that has been introduced in the definition of "recipient" in the 2021 draft regulations excludes a woman who undergoes medically assisted reproduction using her own and her husband's or life partner's gametes. This means that medically assisted reproduction involving women who undergo medically assisted reproduction using their own and their husbands' or life partners' gametes is unregulated. It also leads to various nonsensical results throughout the $2021 \mathrm{draft}$ regulations. For example, the limit of a maximum of two embryos that may be transferred to a "recipient" ${ }^{\text {"62 }}$ is therefore not applicable to a woman whose embryos were created using her husband's or life partner's gametes, meaning that in these cases it would be legal to transfer any number of embryos.

All of these issues would be resolved by simply defining a "recipient" as "a woman who intends to become pregnant through medically assisted reproduction".

\subsubsection{Properly distinguishing between the two envisaged databases}

The 2021 draft regulations contemplate the establishment of two separate databases established by the director-general to store information related to medically assisted reproduction: (a) the central data bank described in regulation 6(1) for storing "all

$\begin{array}{ll}61 & \text { See par } 3.1 .1 \text { above. } \\ 62 & \mathrm{r} 12(2) .\end{array}$ 
information regarding the use of individual donated gametes and assisted conception treatment outcomes"; and (b) the electronic database described in regulation 15(1), which is intended to record the particulars of "authorised institutions" and "competent persons". These are clearly intended as two separate databases that must remain separate for important reasons. The information in (a) must remain confidential to protect donor anonymity, ${ }^{63}$ while the information in (b) is not confidential. ${ }^{64}$ Both (a) and (b) are referred to in the relevant provisions as a "database". However, the definition of the term "database" makes mention of "a database contemplated in regulation 15(1)". This leads to the confusing outcome that the requirements that apply to database (a), as per regulation 6(1), such as that "the database must remain confidential", also apply to database (b). This is clearly not the intended outcome. To remedy this, revised medically assisted reproduction / assisted reproductive technology regulations should remove the definition of "database" and instead use the terminology of a "Registry of Authorised Institution and Persons" to describe database (b).

\subsubsection{The meaning of "competent person"}

The term "competent person" is used to designate a natural person who is authorised to perform medically assisted reproduction procedures, including removing an oocyte from a woman and causing sperm to be removed from a man, ${ }^{65}$ creating embryos in vitro, ${ }^{66}$ and transferring such gametes or embryos to a woman's reproductive organs. ${ }^{67}$ In the 2012 regulations, a competent person is defined as follows:

"in relation to artificial fertilisation means a person registered as such in terms of the Health Professions Act, 1974 (Act No. 56 of 1974); who is -

(a) a medical practitioner specialising in gynaecology with training in reproductive medicine;

(b) a medical scientist, medical technologist, clinical technologist, with training in reproductive biology and related laboratory procedures." 68

The medically assisted reproduction procedures that a competent person is authorised to do in terms of the 2012 regulations - and that remain the same in the $2021 \mathrm{draft}$ regulations - are in practice typically performed not by a single occupational group of persons, but by two separate occupational groups that correspond to (a) and (b) in the definition quoted above. In common language, occupational group (a) is referred to as "fertility specialists", and occupation group (b) as "embryologists". For ease of reading, we adopt these common terms. The typical division of labour is as follows: ${ }^{69}$ Fertility specialists would interface with patients, perform tests, diagnose disorders, provide treatments, and perform procedures like egg harvesting

$63 \mathrm{r} 6(2)$.

${ }_{64}$ This is evident from the provisions in $\mathrm{r} 15$, which make clear that competent persons will be able to access the database. For instance, $\mathrm{r} 15(2)(b)$ provides that a competent person may request to have their particulars removed from the database. This would not be possible if competent persons were not permitted to access this database and be made aware of their particulars being recorded in it.

652012 regulations (n 9) r 3(1); 2021 draft regulations (n 12) r 4(1).

662012 regulations (n 9) r 9(2); 2021 draft regulations (n 12) r 10.

672012 regulations (n 9) r 9(2); 2021 draft regulations (n 12) r 10. Note that the definition of "artificial fertilization" in the 2012 regulations and the definition of "assisted conception" in the $2021 \mathrm{draft}$ regulations are so broad as to include both the creation of embryos in the laboratory and the transfer of these embryos to a woman's uterus.

$68 \mathrm{r} 1$.

69 Heylen, current president of the society, email to the first author, 14 June 2021. 
and embryo transfer. Embryologists, on the other hand, receive the harvested eggs from the fertility specialist, create in vitro embryos using techniques such as intracytoplasmic sperm injection, perform biopsies on the in vitro embryos if required, and culture, monitor and grade the in vitro embryos until they are handed to the fertility specialist for transfer in utero. ${ }^{70}$ This division of labour is not unique to South Africa. Throughout the world, fertility clinics use embryologists, who perform an essential role.

Fertility specialists and embryologists are not interchangeable. While fertility specialists are medical practitioners with a specialisation in gynaecology and a subspecialisation in reproductive medicine, embryologists are medical scientists who specialise in reproductive biology. ${ }^{72}$ These two occupational groups complement each other and are both essential to the successful functioning of modern fertility clinics. However, proposed changes to the definition of "competent person" in the 2016 and 2021 draft regulations threaten the continued existence of these complementary occupational groups in South Africa. In the 2016 draft regulations, a new, narrower definition was proposed for a "competent person":

"a medical practitioner registered with the Health Professions of South Africa (HPCSA) with expertise in specialist gynaecologist [sic] and [who is a] sub-specialist in Reproductive Medicine, or a trainee in Reproductive Medicine in a training unit under the supervision of a registered HPCSA sub-specialist", 73

This is substantively identical to the definition in the 2021 draft regulations, which define a "competent person" as: "a sub-specialist in Reproductive Medicine registered with the Health Professions Council of South Africa (HPCSA), or a trainee in Reproductive Medicine in a training unit working under the supervision of a registered sub-specialist in Reproductive Medicine".74

These proposed new definitions featured in the 2016 and 2021 draft regulations, if implemented, would exclude embryologists. Furthermore, these new definitions would also narrow the scope of medical practitioners who qualify as competent persons from those who have had training in reproductive medicine to only those with a subspeciality in reproductive medicine. Clearly these proposed new definitions would have far-reaching consequences for the medically assisted reproduction industry if they were to be implemented. It is for this reason that there has been an attempt to bar the proposed new definition in the 2016 draft regulations from becoming law. In the Pietermaritzburg Fertility Clinic case, the constitutionality of the definition of "competent person" in the 2016 draft regulations was challenged on the grounds that, if made into law, it would violate the rights of the excluded persons to choose and practise their profession, and would undermine the rights of the general public to access healthcare services. ${ }^{75}$ The challenge ultimately failed,

70 See Choucair, Younis and Hourani "The value of the modern embryologist to a successful in vitro fertilisation system: revisiting an age-old question" 2021 Middle East Fertility Society J 1. For an extended explanation of the function of embryologists in the fertility clinic, see the following interview with leading embryologists: https:/Www.coopergenomics.com/blog/during-ivf/embryologistinterview/ (14-06-2021).

71 See Magli et al "Revised guidelines for good practice in in vitro fertilisation laboratories" 2008 Human Reproduction 1253.

72 See Kovačič et al "The educational and professional status of clinical embryology and clinical embryologists in Europe" 2015 Human Reproduction 1756.

$73 \mathrm{r} 1$.

74 r 1.

75 the Pietermaritzburg Fertility Clinic case (n 19) par 10. 
but because the court deemed it premature to challenge draft regulations and not because of the merits of the constitutional grounds. ${ }^{76}$

Importantly, in making his case before the court, the minister of health made much of the fact that the 2016 draft regulations were merely draft regulations, and thus subject to change. ${ }^{77}$ While the applicants argued that the proposed new definition constitutes a threat to their rights, the minister argued that the constitutional challenge was premature, ${ }^{78}$ since the draft regulations were not yet law and it cannot be assumed that they would become law in their existing form. This proved to be a decisive consideration in the judgment, as the high court per Keightley J took the view that, "it is entirely speculative that the Minister will indeed enact the [2016] Draft Regulations, let alone with the impugned definition of competent person as is". 79 In a cynical turn of events, the impugned definition of "competent person" in the 2016 draft regulations effectively remains the same in the 2021 draft regulations.

It seems that even after hearing the concerns of the applicants in the Pietermaritzburg Fertility Clinic case, the minister still remains adamant on mandating that only medical practitioners with a subspeciality in reproductive medicine perform the functions of a "competent person". While there may be merit in requiring actual subspecialisation in reproductive medicine - rather than merely the vague requirement of "training" in reproductive medicine - to qualify as a fertility specialist, the exclusion of embryologists from the definition of "competent person" would ostensibly stop them from practising their profession. This would in turn have deleterious consequences for reproductive healthcare in South Africa. ${ }^{80}$ However, according to the submissions on behalf of the minister in the Pietermaritzburg Fertility Clinic case, this is not an outcome that would eventuate if the new definition of "competent person" in the 2016 draft regulations were to make it into law.

It was contended on behalf of the minister that it is an erroneous assumption that the new definition of "competent person" would apply retrospectively. ${ }^{81}$ In fact, it was stated under oath on behalf of the minister that if the new definition of "competent person" in the 2016 draft regulations were to be made into law, it would apply only to those who enter into the medically assisted reproduction industry after it came into effect. ${ }^{82}$ But, as the applicants pointed out, this interpretation is not apparent from a plain reading of the definition. Nothing in the text suggests that it does not apply retrospectively. ${ }^{83}$ The same can be said of the 2021 draft regulations. The persons who stand to be excluded by the 2021 draft regulations have no reason to believe that their livelihoods will not be threatened, except the statement on behalf of the minister in the papers filed in the Pietermaritzburg Fertility Clinic case. It is important to note that these statements are not binding and would not prevent retrospective enforcement. If it is truly the intention of the minister not to

76 the Pietermaritzburg Fertility Clinic case (n 19) par 28.

77 the Pietermaritzburg Fertility Clinic case (n 19) par 5.

78 the Pietermaritzburg Fertility Clinic case (n 19) par 16.

79 the Pietermaritzburg Fertility Clinic case (n 19) par 23.

80 The reasons for this were explained by Moodley in par 50 to 52 of the founding affidavit in the Pietermaritzburg Fertility Clinic case (n 19): "The embryologist has a crucial role to play at any fertility clinic: It is the laboratory scientist/technologist who is skilled in doing in vitro fertilisation (bringing the human egg and sperm together in the laboratory) - either by injecting a single sperm cell directly into the cytoplasm of an egg (intracytoplasmic sperm injection) or through other, older techniques. ... The effect of the definition as per the draft Regulations is therefore the complete paralysis of the laboratories of all fertility clinics in our country."

81 the Pietermaritzburg Fertility Clinic case (n 19) par 17.

82 the Pietermaritzburg Fertility Clinic case (n 19) first respondent's answering affidavit par 43, 44, 56.

83 the Pietermaritzburg Fertility Clinic case (n 19) applicants' replying affidavit par 10. 
apply the new definition retrospectively, it is incomprehensible why - in the wake of the Pietermaritzburg Fertility Clinic case - this has not been explicitly stated in the definition of "competent person" in the 2021 draft regulations.

If it is accepted, however, that the new definition would not deprive any persons who are already in practice of their livelihood, there are still concerning, longterm consequences if this definition becomes law. The consequences would, over time, entail terminating the profession of embryologist in South Africa, while all functions currently performed by embryologists would - out of sheer necessity have to be performed by fertility specialists. All this considered, one must ask: What does South Africa stand to gain by departing from international best practice in reproductive healthcare by deliberately terminating the role of embryologists and replacing them with subspecialised medical practitioners? We suggest that there is no gain in such a move. In the absence of evidence to the contrary, this would be an unwise course of action that would lead to the undue demise of clinical embryology in South Africa - a discipline which is growing in other parts of the world. ${ }^{84}$

Instead, what a revision to the definition of "competent person" ought to do is to recognise the division of labour in reproductive healthcare and to recognise both fertility specialists and embryologists, rather than attempting to conflate their roles under the monolithic definition of "competent person". There should be a definition for "fertility specialist" and "embryologist" respectively, and these terms should be used throughout the regulations to accurately reflect practice.

\subsection{Procurement of sperm only through self-stimulation}

The 2021 draft regulations introduce a provision that reads: "For purposes of assisted conception, male gametes must be procured only after self-stimulation". ${ }^{85}$ The effect of this provision would be to ban sperm retrieval by any means other than selfstimulation. It is unclear what mischief motivated the inclusion of this provision. What is clear is how it would shut the door on various groups of persons from having a child using medically assisted reproduction: men who cannot provide sperm via self-stimulation for medical reasons, men who cannot provide sperm via selfstimulation for religious or cultural reasons, and spouses who wish to procure sperm from a comatose or deceased husband for the purpose of posthumous conception. We explain below how the self-stimulation requirement affects each of these groups.

\subsubsection{Men who cannot provide sperm via self-stimulation for medical reasons}

Men who cannot ejaculate, or whose ejaculate produces a zero sperm count (due to conditions such as azoospermia) may use surgical sperm retrieval techniques such as testicular sperm aspiration. ${ }^{86}$ These interventions are important because they are the only way men who suffer from infertility can have children using their own sperm. However, the self-stimulation requirement would deprive these men of these techniques to realise their ambitions of having children of their own. This would further exacerbate the psychological distress that is already associated

84 See Kovačič et al "ESHRE Clinical Embryologist certification: the first 10 years" 2020 Human Reproduction Open 1.

$85 \mathrm{r} 4(2)$.

86 See Esteves, Miyaoka, Orosz and Agarwal "An update on sperm retrieval techniques for azoospermic males" 2013 Clinics 99. 
with diagnosed male infertility. ${ }^{87}$ This is potentially a violation of these men's right to equality, ${ }^{88}$ in that the self-stimulation requirement discriminates against them based on a disability. ${ }^{89}$ A similar argument can be made for men who are not necessarily infertile, but who suffer from medical conditions or injuries that make self-stimulation impossible.

\subsubsection{Men who cannot provide sperm via self-stimulation for religious or cultural reasons}

There are well documented religious and cultural norms against male self-stimulation, because of which certain men can only use medically assisted reproduction if sperm is procured by alternative means (such as with the assistance of a spouse). For instance, this is the reason why some Christian and Muslim denominations permit their adherents to use medically assisted reproduction methods only where sperm retrieval can occur subsequent to sexual intercourse. ${ }^{90}$ For men who hold these religious convictions (and their partners) these methods allow them to use medically assisted reproduction, while still living within the prescripts of their faith. And given that the constitution entrenches the right to freedom of religion, the selfstimulation requirement would potentially be an infringement of this right.

\subsubsection{Spouses who wish to procure sperm from a comatose or deceased husband for the purpose of posthumous conception}

Gamete cryopreservation technology, combined with in vitro fertilisation, has made it possible for the surviving spouses of deceased men to use their sperm in order to have a child after the man's death. This is a practice called "posthumous conception", and it gives couples the opportunity to fulfil their desire to have children even after one of them has died. In the Aevitas case the high court confirmed that posthumous conception is in principle legal. ${ }^{93}$ If a spouse becomes severely ill or dies suddenly, medical intervention is necessary to make posthumous conception possible. This is precisely what occurred in the Ex parte $S N$ case, where a wife sought to have her dying, comatose husband's sperm procured from his body. ${ }^{94}$ The court granted the wife's application for an order confirming that as the man's spouse she had the authority to consent to surgical gamete removal on his behalf. ${ }^{95}$ In so doing, the court enabled her to carry the child she and her husband had always wanted to have. The self-stimulation requirement would roll back the hard-won progress made in

87 Fisher and Hammarberg "Psychological and social aspects of infertility in men: an overview of the evidence and implications for psychologically informed clinical care and future research" 2021 Asian J Andrology 123. See also Joja, Dinu and Paun "Psychological aspects of male infertility. An overview" 2015 Procedia - Social and Behavioral Sciences 359.

88 s 9.

89 Shozi (n 13) 20. As Shozi points out, given that infertility is widely recognised as a disability, it falls within the listed grounds in s 9(3).

90 Salam and Salam "Religious aspects of assisted reproduction" 2016 Facts, Views \& Vision in ObGyn 36.

$91 \mathrm{~S} 15$.

92 Shozi A Human Rights analysis of Posthumous Reproduction (2019 LLM dissertation KZN) 2.

$93 \mathrm{n} 16$.

94 n 17.

95 Shozi (n 17). 
the Ex parte $S N$ case, as sperm removal from a comatose man would be rendered unlawful.

It is important to recognise the rights and values that inform posthumous conception. First, respect for a husband's reproductive autonomy before he entered into a coma or died. ${ }^{96}$ Secondly, the spouse's interest in having a child that shares a genetic link with the comatose or deceased husband. This interest, we suggest, would qualify for protection under the right to reproductive autonomy. ${ }^{97}$ Thirdly, the public interest in respecting the wishes of the deceased. ${ }^{98}$ The self-stimulation requirement ostensibly infringes on reproductive autonomy and undermines the public interest.

\subsubsection{Conclusion on the self-stimulation requirement}

For all the above reasons, we suggest that the self-stimulation requirement ought to be removed. If this is not done it seems inevitable that the provision will invite litigation from members of the three affected groups because of the extent to which it infringes upon their rights and fundamental freedoms.

In the context of posthumous conception, a more nuanced approach that would be aligned with the rights of those involved and with the public interest, would be to replace the self-stimulation requirement with another requirement. This would be that, in the event a man is comatose or recently deceased his spouse has the right to have his sperm surgically removed for purposes of medically assisted reproduction, except if there is evidence that the man, prior to being comatose or deceased, indicated that he did not wish to have children generally or that he did not wish to have children after his death. ${ }^{99}$

\subsection{Preparing for the future of heritable human genome editing}

Genome editing ${ }^{100}$ (or gene editing) refers to modifying an organism's DNA through targeted adding, replacing or removing one or more DNA base pairs. When genome editing is performed in early-stage embryos, eggs, or sperm, the modification to the DNA is intended to be heritable - that is, it is intended to affect not only the resulting person, but also his or her genetic offspring. This may allow certain genetic conditions to be eliminated from a family's bloodline. Heritable human genome editing may also be used to enhance future generations so that they are immune to certain illnesses, or, more controversially (and further into the future), enhance characteristics and abilities that are not related to preventing disease.

Thaldar et $a l^{101}$ analyse the current South African legal landscape related to heritable human genome editing, and identify two statutes that may potentially regulate its clinical application - that is, using heritable human genome editing qua assisted reproductive technology. The first is the Medicines and Related Substances Control Act 101 of 1965 . The authors suggest that the DNA and viral vectors used

96 Thaldar (n 16) 472.

97 s 12(2)(a). See also Shozi (n 92) 16.

98 Shozi (n 92) 31.

99 For a more detailed analysis of this issue, see Shozi (n 92).

${ }^{100}$ See regarding terminology: National Academy of Medicine, National Academy of Sciences and the Royal Society "Heritable Human Genome Editing” 2020.

101 Thaldar et al "Human germline editing: legal-ethical guidelines for South Africa" 2020 S Afr J Sci 1. For a more comprehensive analysis of the current South African legal landscape related to heritable human genome editing, see Townsend and Shozi "Altering the human genome: mapping the genome editing regulatory system in South Africa” 2021 PELJ 1. 
in heritable human genome editing may qualify as medical devices, hence bringing it within the regulatory orbit of the South African Health Products Regulatory Authority. However, the South African Health Products Regulatory Authority does not have guidelines for heritable human genome editing.

The second statute identified by Thaldar et al that may potentially regulate the clinical application of heritable human genome editing is Act 61 of 2003 - in particular section 57, which deals with human cloning. The reason human cloning provisions may be applicable to heritable human genome editing is because of the ambiguous definition of "reproductive cloning of a human being" as "the manipulation of genetic material in order to achieve the reproduction of a human being and includes nuclear transfer or embryo splitting for such purpose". "If "the reproduction of a human being" is broadly interpreted as "human reproduction", heritable human genome editing would qualify as cloning, rendering it unlawful. On the other hand, if "the reproduction of a human being" is narrowly interpreted as "the replication/copying of a human being", heritable human genome editing would not qualify as cloning, so placing it beyond the ambit of section 57 . We suggest that this narrow interpretation is to be preferred in our law, with reference to the principles of statutory interpretation. ${ }^{103}$ Our reasons include the following: (i) the broad interpretation of "the reproduction of a human being" as "human reproduction" is forced and divorced from the context of the rest of section 57; (ii) given the historical context at the time of the enactment of Act 61 of 2003, namely societal concerns about the advent of cloning technology and the possibility of cloning humans, the mischief that section 57 was intended to address is human cloning - not any other technology; (iii) the ethical concerns with human cloning primarily centre on human individuality and genetic uniqueness. These concerns are simply not applicable to heritable human genome editing; and (iv) the commonlaw presumption in favour of the least restrictive interpretation ${ }^{104}$ favours the narrow interpretation of "the reproduction of a human being" as "the replication/copying of a human being". 105

Now that section 57 has been dealt with, the analysis can proceed to more fertile ground, namely the ways in which Act 61 of 2003 does apply to the clinical use of heritable human genome editing. Thaldar et al suggest that pre-clinical and clinical trials of heritable human genome editing would be subject to ethics clearance by a health research ethics committee in terms of section 73. Furthermore, the minister of health is empowered by section $68(1)(k)$ to regulate research on embryos, and by section $68(1)(l)$ to regulate "artificial fertilisation of persons" - the old terminology that approximates medically assisted reproduction. Accordingly, the minister has the power to regulate the clinical use of heritable human genome editing. We suggest

102 s 57 - emphasis added.

103 Thaldar et al (n 101) arrive at a similar conclusion, but add the rider that in light of the absence of case law on the subject, this legal position cannot be stated with certainty. See also Soni "The brave new world: should we tread down the path to human germline editing?" 2021 SAJBL 24. The author suggests that a purposive approach would favour a broad interpretation of s 57 , as "the objective behind this provision was to prevent genetic manipulation of the human genome in a manner that is heritable, hence the reference to gametes, embryos and zygotes". It is a leap of logic to suggest that a reference to gametes, embryos and zygotes indicates an intention to outlaw all heritable genetic interventions. In fact, cloning itself is not heritable. As such, the author's statement is clearly mistaken. The author fails to provide any other reason for believing that the purpose of s 57 is to outlaw heritable human genome editing. Accordingly, the author's argument does not convince.

${ }^{104}$ Rossouw v Sachs 19642 SA 551 (A) 562D-E: "if a statute is couched in ambiguous language, the court will give it the meaning which least interferes with the liberty of the individual".

105 Townsend and Shozi (n 101) 10. 
that the time has arrived for the minister to use this power. The over-hasty use of heritable human genome editing by a rogue scientist in China amplifies the urgency of properly and clearly regulating heritable human genome editing.

Based on South Africa's constitutional values, Thaldar et al ${ }^{106}$ developed five principles to guide legal development regarding heritable human genome editing in South Africa. These principles are as follows:

Principle I: Given its potential to improve the lives of the people of South Africa, heritable human genome editing should be regulated, not banned.

Principle II: Heritable human genome editing's clinical applications should be made accessible to the public only if they are proven to be safe and effective.

Principle III: Non-therapeutic heritable human genome editing should be regulated in the same way as therapeutic heritable human genome editing, with the rider that it should not in any legally relevant sense cause harm.

Principle $I V$ : The decision whether to use heritable human genome editing in a prospective child, should, subject to principles I, II, and III, be left to the prospective parents.

Principle V: Concerns about exacerbating social inequalities should be addressed by measures to increase access.

The publication of the $2021 \mathrm{draft}$ regulations for public comment provides an ideal opportunity for South Africa to lead the world by being the first country to introduce legislation that regulates (qua middle ground between unregulated use and banning, following principle I) the clinical application of heritable human genome editing. We suggest that the principles above can be translated into medically assisted reproduction regulatory provisions as follows:

A1 The genomes of gametes and embryos may be edited only if such edit is part of a pre-clinical trial or clinical trial that is: -

(a) approved by a health research ethics committee registered as such with the National Health Research Ethics Council, and

(b) in the event of a clinical trial, registered with the South African Health Products Regulatory Authority.

A2 Sub-regulation A1 shall cease to have effect after ten years from the date of promulgation of these regulations, unless the minister of health gives notice in the Government Gazette that the effect of the sub-regulation is extended for a specified period not exceeding five years.

A3 The genomes of gametes and embryos may not be edited if such an edit is likely to have an effect on the prospective child that would constitute either a civil or criminal wrong in law if caused by an act by a parent toward an existing child.

A4 Subject to sub-regulation A1 and sub-regulation A3, the recipient and, if applicable, the recipient's spouse or life partner, have the right to decide whether to have the genomes of their gametes or embryos edited.

In line with principle II, sub-regulations A1 and A2 aim to ensure that heritable human genome editing is only publicly accessible if it is proven to be safe and effective. Currently, the safety and efficacy of heritable human genome editing has not yet been established. Establishing its safety and efficacy can be done only

106 Thaldar et al (n 101). 
through pre-clinical trials, followed by clinical trials. Sub-regulation A1 recognises this current reality and provides for the use of heritable human genome editing within the limited context of pre-clinical or clinical trials. It also makes it clear that such trials must obtain ethics clearance (as contemplated in Act 61 of 2003), and that clinical trials must be registered with the South African Health Products Regulatory Authority (as contemplated in the Medicines and Related Substances Control Act 101 of 1965).

Sub-regulation A2 makes A1 subject to a sunset clause. Assuming that a safe and effective way to use heritable human genome editing will be established within the next decade, the purpose served by sub-regulation A1 will be rendered irrelevant. The sunset clause in sub-regulation A2 will then ensure that sub-regulation A1 retires. In the event that the assumption turns out not to be accurate, in other words that a safe and effective way to use heritable human genome editing is not established within a decade, A2 provides for an easy way to keep sub-regulation A1 alive - namely by notice in the Government Gazette. Importantly, such notices can extend the operation of sub-regulation A1 only for a maximum period of five years at a time, in order to avoid sub-regulation A1 becoming a permanent, and possibly outdated, statutory fixture.

Principle III finds expression in sub-regulation A3. Once heritable human genome editing has been established as safe and effective, it can be used like any other assisted reproductive technology. However, an edit may be safe for the health of a prospective child but may in other ways cause legally relevant harm to the prospective child once the child is born. The idea that the law should protect the prospective child from harm is the implicit cornerstone of both the constitutional court's minority and majority judgments in the $A B$ case. We suggest that the appropriate solution for establishing harm in the context of using heritable human genome editing qua assisted reproductive technology is to rely on the existing standards of wrongfulness in our law. ${ }^{107}$ This can be accomplished by comparing the likely effect on the prospective child of the edit in question with a similar effect on a hypothetical child in esse caused by any hypothetical act: If the edit is likely to have an effect on the prospective child that would constitute either a civil or criminal wrong in law if caused by an act by a parent toward an existing child, the edit should be deemed harmful to the prospective child and be prohibited. ${ }^{108}$ For example, if the edit in question will make the prospective child deaf, the edit would be prohibited, because if any person intentionally causes an existing child to become deaf such an act would certainly be deemed a criminal (and a civil) wrong.

Giving effect to principle IV, sub-regulation A4 provides that the prospective parent or parents - not the government or health practitioners - have the right to decide whether to use heritable human genome editing as assisted reproductive technology for their prospective children. This is subject, of course, to subregulations $\mathrm{A} 1$ and $\mathrm{A} 3$. This right flows from the constitutional right to make decisions regarding reproduction. While the majority in the $A B$ case was silent on the issue of whether the use of assisted reproductive technology falls within the ambit of the constitutional right to make decisions regarding reproduction, the minority in the $A B$ case, per Khampepe J, clearly embraced this view - therefore setting a persuasive precedent. ${ }^{109}$ We suggest that this is aligned with the generous approach to the interpretation of constitutional rights in South Africa's constitutional

\footnotetext{
107 Thaldar and Shozi (n 15).

108 Thaldar and Shozi (n 15).

109 the $A B$ case (n 6).
} 
jurisprudence, perhaps best exemplified by the following quote from the judgment penned by Sachs J in Minister of Home Affairs $v$ Fourie:

"Indeed, rights by their nature will atrophy if they are frozen. As the conditions of humanity alter and as ideas of justice and equity evolve, so do concepts of rights take on new texture and meaning. The horizon of rights is as limitless as the hopes and expectations of humanity.",110

\section{Overview of the provisions that are sub judice}

The following provisions of the 2012 regulations are impugned in the Surrogacy Advisory Group case: (i) The requirement that a married couple or a couple in a permanent relationship must submit to psychological evaluation when they use each other's gametes for medically assisted reproduction; (ii) the ban on pre-implantation non-therapeutic sex selection; and (iii) the blanket ban on disclosing that one has used medically assisted reproduction, donated gametes towards medically assisted reproduction, or was conceived using medically assisted reproduction. For the sake of comprehensiveness, we provide a brief overview of each of these impugned provisions, but intentionally refrain from expressing an opinion on them. Where relevant, we do, however, analyse ancillary issues that have bearing on the revision of the regulations, but not on the case itself.

\subsection{Psychological evaluation}

Donor gametes from anonymous gamete donors can be accessed at local or international gamete banks or donation agencies. Some South African fertility clinics also offer their own in-house databases of anonymous gamete donors that their patients can access. ${ }^{111}$ An alternative to using the gametes of an anonymous gamete donor is to use the gametes of a gamete donor who is known to one, such as a sibling or friend. ${ }^{112}$

The 2012 regulations provide that, in the event that a recipient intends to use a known gamete donor, the competent person must ensure that both the recipient and the known gamete donor undergo a psychological evaluation. ${ }^{113}$ However, as a consequence of the definition of "gamete donor" in the 2012 regulations, which includes the recipient's husband or life partner, psychological evaluation is mandatory in cases where a recipient intends to use the sperm of her husband or life partner. The Surrogacy Advisory Group argues that, to the extent that this provision makes psychological evaluation compulsory where a recipient intends to use the sperm of her husband or life partner, it infringes on (i) equality, (ii) privacy, and (iii) access to healthcare services.

The 2021 draft regulations resolve this issue in two ways. Firstly, as already pointed out above, ${ }^{115}$ the new definition of "gamete donor" in the 2021 draft regulations does not include a husband or life partner, as they are not donating their sperm to other intended parents; rather, together with the recipient, they are the intended parents of the child and will be using their own sperm for such purpose. Accordingly, the new definition of "gamete donor" would fully address the Surrogacy Advisory Group's

\footnotetext{
${ }^{110}$ Minister of Home Affairs v Fourie 20061 SA 524 (CC) par 102.

111 the Surrogacy Advisory Group case (n 20) Rodrigues expert opinion par 9.

112 the Surrogacy Advisory Group case (n 20) Rodrigues expert opinion par 10.

113 r 7(j)(ii).

114 the Surrogacy Advisory Group case (n 20) founding affidavit par 27-43.

115 See par 2.1 above.
} 
concerns. Secondly, the psychological evaluation provision has been removed in toto from the 2021 draft regulations. Although this would obviously remove the cause of the dispute regarding this impugned provision, the Surrogacy Advisory Group responded with caution, stating that complete removal of the provision is not what was intended. ${ }^{116}$

In the following paragraphs, we critically analyse the wisdom of the intended complete removal of the psychological evaluation provision in the $2021 \mathrm{draft}$ regulations. Note that this analysis will assume that "gamete donor" is defined as per its new definition in the 2021 draft regulations (as excluding intended parents themselves), which means that the psychological evaluation provision would apply only where a recipient intends to use a known gamete donor in the ordinary sense of these words - not where a recipient intends to use the sperm of her husband or life partner.

Reasons for retaining the psychological evaluation provision for known gamete donors (as per the new definition) can be found in the expert psychological opinion by Ms Samouri, filed by the Surrogacy Advisory Group. These reasons revolve around the fact that although the gamete donor will be the genetic parent, he or she will not be the legal parent of the donor-conceived child. ${ }^{117}$ Given that the recipient and the gamete donor are known to each other, questions arise about issues such as contact with the child, and disclosure of the donor's role in the child's conception to the child. From the perspective of avoiding possible legal disputes, it can be argued that it is preferable to have a psychologist involved to investigate whether the donor's expectations regarding his or her involvement, if any, in the child's life, are aligned with the way in which the recipient and her spouse or life partner, if any, are planning their family life. However, while psychological evaluation may minimise the risk of legal disputes arising, it provides no guarantee.

The unique dynamics of known gamete donation confronted the court in the recent case of $Q G v C S{ }^{118}$ In this case, a lesbian couple had a son by using sperm from a known sperm donor. The donor had only occasional contact with the child, until the child's fourth year, when the lesbian couple started renting a cottage on the sperm donor's smallholding, and during which time contact between the donor and the child increased. However, the relationship between the couple and the donor soured, and they moved after just nine months and stopped granting the donor access to the son. This led to litigation in which the donor sued for parental rights and responsibilities. This is despite having signed a sperm donor agreement prior to donation in which he agreed never to seek parental rights and responsibilities. What is noteworthy for present purposes is that the sperm donor alleges that he did not undergo psychological evaluation, and that the competent person involved never requested him to do so. Had the competent person complied with the 2012 regulations by ensuring that the sperm donor underwent psychological evaluation, it is an open question whether the unfortunate turn of events could have been avoided. Accordingly, $Q G v C S$ can be perceived as vindicating the importance of retaining psychological evaluation for known gamete donors.

However, a counterargument can also be made based on $Q G v C S$. It is the first case of its nature in South Africa and therefore occurred within a legal context where certain aspects of the law were not yet clear. The Pretoria high court held in favour

\footnotetext{
${ }^{116}$ Surrogacy Advisory Group Submission Regarding the Draft Regulations Relating to the Assisted Conception of Persons (17 June 2021).

117 the Surrogacy Advisory Group case (n 20) Samouri expert opinion par 8, 10.

${ }^{118}$ n 18.
} 
of the lesbian couple, rejected the sperm donor's application for parental rights and responsibilities, and slammed him with a cost order. Currently, the sperm donor is applying for leave to appeal, so the case may still proceed. Whatever the outcome of the application for leave to appeal and a possible appeal, the case of $Q G v C S$ will establish the first legal precedent in South Africa regarding the rights - if any - of known gamete donors in respect of donor-conceived children, and hence provide legal certainty for all involved in known gamete donation. This legal certainty will contribute to managing future known gamete donors' expectations regarding their involvement in the donor-conceived child's life, which can be perceived as lessening the need to prescribe psychological evaluation.

Lastly, retaining the psychological evaluation provision would come at a financial cost to the intended parents - in addition to the medical costs of medically assisted reproduction. These are all costs that people who can procreate without the need for medically assisted reproduction do not need to bear. ${ }^{19}$ On the other hand, it can be argued that it is reasonable to differentiate, as known gamete donation is still a relatively new cultural phenomenon that people have limited experience in handling in their everyday social interactions, and that prescribing psychological evaluation - to protect the interests of all involved - is therefore justified. Accordingly, we suggest that there are reasonable arguments on both sides, and that the scales are in equipoise from a policy perspective.

\subsection{Pre-implantation testing for sex selection}

Using a technology called pre-implantation genetic testing for aneuploidy, it is possible to know which in vitro embryos are male and which are female, and then to transfer only those with the desired sex to a recipient's uterus. Pre-implantation genetic testing for aneuploidy entails that a biopsy sample of a few cells is taken from an in vitro embryo, which is then genetically tested to ascertain whether the embryo is chromosomally competent (euploid) or whether it has chromosomal abnormalities (aneuploidy) such as Down Syndrome. Given that pre-implantation genetic testing for aneuploidy provides information on all the chromosomes, it also reveals whether the embryo is male or female. This information can then be used by prospective parents who desire a child of a certain sex. Prior to the promulgation of the 2012 regulations, pre-implantation sex selection was offered as a service to fertility patients by some South African fertility clinics. This changed with the promulgation of the 2012 regulations that provide as follows: "Pre-implantation and prenatal testing for selecting the sex of a child is prohibited except in the case of a serious sex linked or sex limited genetic conditions.",120

The Surrogacy Advisory Group argues that this provision infringes women's (i) right to bodily and psychological integrity; (ii) privacy; and (iii) non-discrimination based on religion or belief system. ${ }^{121}$ The provision has also been controversial in the academic literature, with two South African legal scholars highlighting the problematic implications thereof. ${ }^{122}$

\footnotetext{
119 See Jordaan "A constitutional critique on the regulations relating to artificial fertilisation of persons" 2017 S Afr J Bioethics Law 29.

$120 \mathrm{r} 13$.

121 the Surrogacy Advisory Group case (n 20) founding affidavit par 55-83.

122 Thaldar "Is it time to reconsider the ban on nontherapeutic pre-implantation sex selection?" 2019 SALJ 223; Soni "Prêt-à-porter procreation: contemplating the ban on preimplantation sex selection" 2019 PELJ 1 .
} 
The 2021 draft regulations removed reference to prenatal testing, but retained the ban on pre-implantation testing for non-therapeutic sex selection: "Pre-implantation testing for selecting of the sex of an embryo is prohibited except in the case of serious sex linked or sex limited genetic conditions." ${ }^{123}$

The Surrogacy Advisory Group indicated that this proposed amendment fails to resolve the dispute regarding this impugned provision. ${ }^{124}$ Accordingly, the issue of pre-implantation sex selection is currently set to be adjudicated by the court.

\subsection{Disclosure of certain facts}

It should be evident that persons who undergo, donate towards, or result from medically assisted reproduction have privacy interests regarding their own involvement in medically assisted reproduction. The 2012 regulations therefore place a blanket ban on any communication by any person - including persons who underwent, donated towards, or resulted from medically assisted reproduction themselves - about any matter related to such involvement in medically assisted reproduction. ${ }^{125}$ The Surrogacy Advisory Group presented evidence that many persons who undergo, donate towards, or result from artificial fertilisation themselves prefer and elect to be open about their experience with family and friends, ${ }^{126}$ and argue that this provision infringes upon (i) the right to privacy, since it limits discussion of a person's involvement in medically assisted reproduction to such person's own intimate circle of family and friends; and (ii) the right to freedom of expression, since it limits such person's sharing of his or her experiences with medically assisted reproduction with the wider world. ${ }^{127}$

The 2021 draft regulations introduce an amended version of the impugned provision. ${ }^{128}$ The amended version limits the disclosure ban to fertility clinics and their staff. The Surrogacy Advisory Group indicated that this amended version would be acceptable and would resolve the legal dispute regarding this impugned provision. $^{129}$

\section{Conclusion}

In the days when carnival games targeted adults, those who ran these games would offer prizes such as cigars to those who plied their skills successfully. For those who made a valiant effort but ultimately failed to overcome the challenges of these games, the game masters could only console them with the words "close, but no cigar". A reading of the 2021 draft regulations leaves one with the impression that a valiant effort was made to remedy the flaws of the 2012 regulations and the 2016 draft regulations, and thus those responsible deserve praise. However, ultimately, the 2021 draft regulations fall short of the standards to be expected of national regulations on medically assisted reproduction. Much like a carnival game, regulating medically assisted reproduction is a tricky task, but it is definitely not an insurmountable one.

\footnotetext{
123 r 13.

${ }^{124}$ Surrogacy Advisory Group (n 116).

${ }^{125} \mathrm{r} 19$.

126 the Surrogacy Advisory Group case (n 20) Samouri expert opinion par 19-27.

127 the Surrogacy Advisory Group case (n 20) founding affidavit par 90-105.

$128 \mathrm{r} 18$.

129 Surrogacy Advisory Group (n 116).
} 
In this article, we have identified the main areas of concern in the $2021 \mathrm{draft}$ regulations and suggested how these issues can be resolved. In sum: (i) the definitions need to be consistent, coherent, and aligned with international consensus terminology; (ii) procurement of sperm must not to be confined to self-stimulation, and (iii) heritable human genome editing must be regulated. With the changes proposed above, we believe that clear, coherent, and well-founded regulation of medically assisted reproduction is a prize that South Africa may yet win.

\section{RULES OF INTERPRETATION}

"The importance of both text and context to the process of construction is usefully summarised by Lord Hodge in Wood v Capita Insurance Services 2017 UKSC 24 and is uncontroversial. The Supreme Court was concerned with construing an indemnity clause in a share purchase agreement, but this is of general application. At paragraph 13, Lord Hodge said, 'Textualism and contextualism are not conflicting paradigms in a battle for exclusive occupation of the field of contractual interpretation. Rather, the lawyer and the judge, when interpreting any contract, can use them as tools to ascertain the objective meaning of the language which the parties have chosen to express their agreement. The extent to which each tool will assist the court in its task will vary according to the circumstances of the particular agreement or agreements. Some agreements may be successfully interpreted principally by textual analysis, for example because of their sophistication and complexity and because they have been negotiated and prepared with the assistance of skilled professionals. The correct interpretation of other contracts may be achieved by a greater emphasis on the factual matrix, for example because of their informality, brevity or the absence of skilled professional assistance. But negotiators of complex formal contracts may often not achieve a logical and coherent text because of, for example, the conflicting aims of the parties, failures of communication, differing drafting practices, or deadlines which require the parties to compromise in order to reach agreement. There may often therefore be provisions in a detailed professionally drawn contract which lack clarity and the lawyer or judge in interpreting such provisions may be particularly helped by considering the factual matrix and the purpose of similar provisions in contracts of the same type. The iterative process ... assists the lawyer or judge to ascertain the objective meaning of disputed provisions" Royal Commonwealth Society for the Blind v Beasant 2021 EWHC 2315 (Ch) par 23. 